\title{
Salticidae (Arachnida: Araneae) from Oriental, Australian and Pacific Regions, XVI. New Species of Grayenulla and Afraflacilla
}

\author{
MAREK ŻABKA ${ }^{1 *}$ AND MichaEL R. GRAY ${ }^{2}$ \\ ${ }^{1}$ Katedra Zoologii AP, 08-110 Siedlce, Poland \\ zabka@ap.siedlce.pl \\ ${ }^{2}$ Australian Museum, 6 College Street, Sydney NSW 2010, Australia \\ mikeg@amsg.austmus.gov.au
}

\begin{abstract}
Four new species, Grayenulla spinimana, G. wilganea, Afraflacilla gunbar and A. milledgei, are described from New South Wales and Western Australia. Remarks on relationships, biology and distribution of both genera are provided together with distributional maps.
\end{abstract}

ŻABKA, MAREK, \& MichaEl R. GRAY, 2002. Salticidae (Arachnida: Araneae) from Oriental, Australian and Pacific regions, XVI. New species of Grayenulla and Afraflacilla. Records of the Australian Museum 54(3): 269-274.

In comparison to coastal parts of the Australian continent, Salticidae from inland Australia are still poorly studied. Preliminary data indicate that the inland dry areas have their own, endemic fauns, genera Grayenulla and Afraflacilla being good examples (Żabka, 1992, 1993, unpubl.).

At present, seven species of Grayenulla are known from scattered localities in Western Australia. Even if found in coastal areas, they are limited in occurrence to savannah and semidesert habitats, being either ground or vegetation dwellers. The relationship of this genus to others is puzzling. Grayenulla shows some morphological similarities to South American Hisucattus, Asiatic Synagelides and Australian Pseudosynagelides (Galiano, 1987; Bohdanowicz, 1988; Żabka, 1991).

The genus Afraflacilla was first recorded from Australia by Żabka (1993). Seven species, including those described here, are known from locations scattered across the continent; individuals occupy tree trunks in savannah woodland and in open sclerophyll forests. The genus as a whole is very widespread, ranging from west Africa through the Middle East, southern Asia, New Guinea and Australia to western and middle Pacific islands. There are about 50 species known worldwide, most of them are described in Pseudicius (e.g., Prószyński, 1992; Berry et al., 1998). Festucula, Marchena and Pseudicius are the closest relatives of Afraflacilla and they form a monophyletic group.

\section{Material and methods}

This study is based on material from the Australian Museum, Sydney (AMS) and the Western Australian Museum, Perth (WAM). Terminology and the method of specimen examination and measurement follow Żabka (1992, 1993).

Abbreviations used are as follows: AEW, anterior eyes width; AL, abdomen length; CL, cephalothorax length; CW, cephalothorax width; EFL, eye field length; PEW, posterior eyes width. 

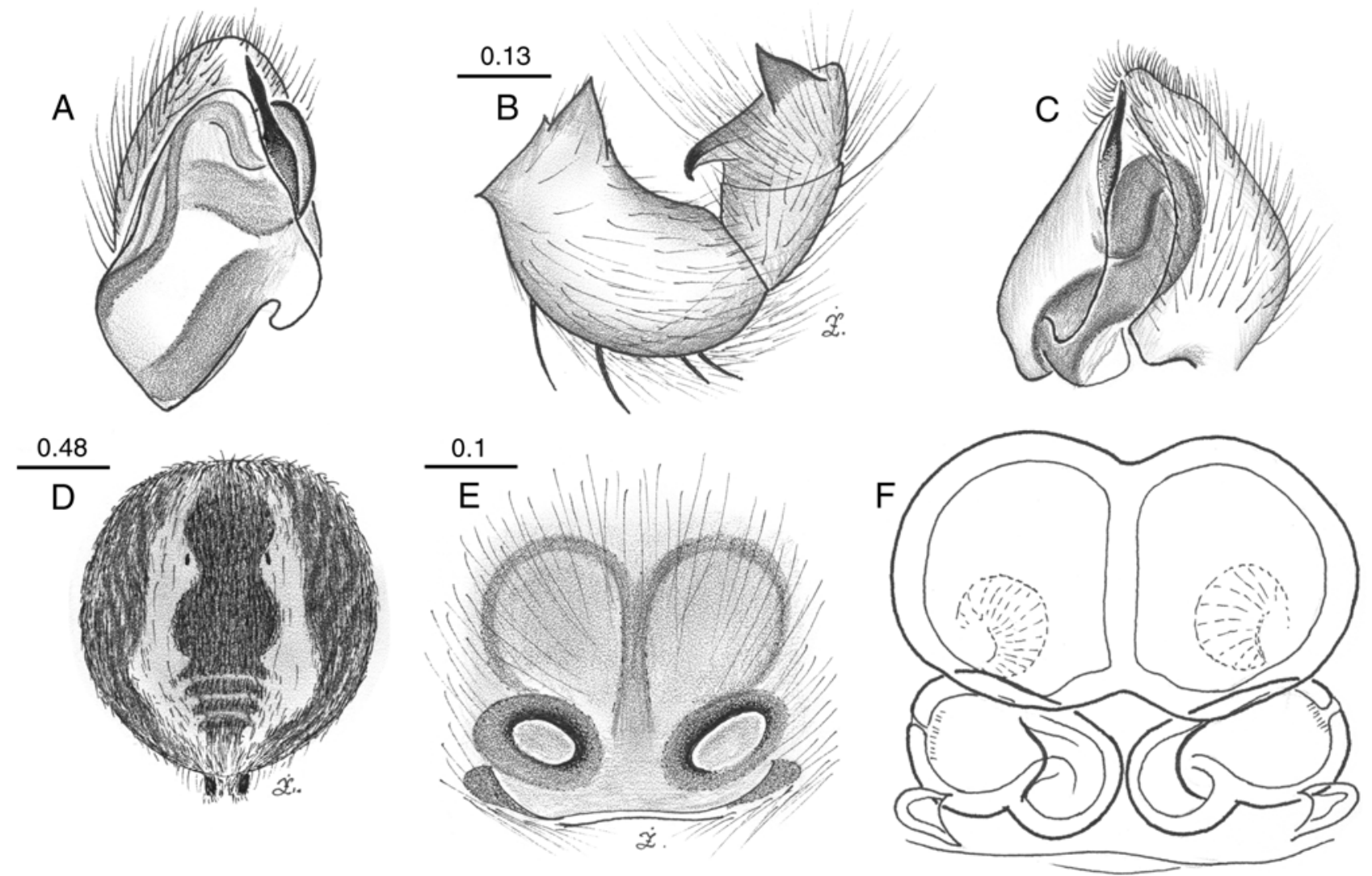

Figure 1. Grayenulla spinimana n.sp.: A-C, palpal organ; D, male abdominal pattern; E, epigyne; F, internal genitalia.

\section{Genus Grayenulla Żabka, 1992}

Grayenulla Żabka, 1992: 175.

Type species Grayenulla dejongi Żabka, 1992, by original designation.

\section{Grayenulla spinimana n.sp.}

Fig. 1

Type material. HoLOTYPE Australia: Western Australia: $\widehat{0}$,

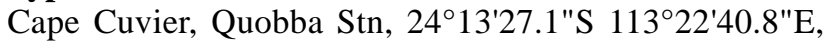
WAM/CALM Carnavon Survey, wet pits, P. West et al., 21 Aug-29 Sep 1994, WAM 99/2185. PARATYPES Australia: Western Australia: 40ิ, Cape Cuvier, Quobba Stn, $24^{\circ} 13^{\prime} 27.1^{\prime \prime S} 113^{\circ} 22^{\prime} 40.8^{\prime \prime E}$, WAM/CALM Carnavon Survey, wet pits, 21 Aug-29 Sep 1994, P. West et al., WAM 99/2186-9; 20 , same data, WAM 99/2176-7; 50, same data, WAM 99/2191-5; $\hat{\partial}$, same data, WAM 99/2196; 40, same data, WAM 99/2178-81; $2 \hat{o}, 1 j$, same data, 15 Jan30 May 1995, A. Sampey et al., WAM 99/2182-4; خे, same data, WAM 99/2190; 1 \%, same data, WAM 99/2197; $10^{\star}$, Kennedy Range NP, $24^{\circ} 29^{\prime} 33.7^{\prime \prime S} 115^{\circ} 01^{\prime} 50.1^{\prime \prime E}$, wet pits, 18 Aug-6 Oct 1994, M. Harvey et al., WAM 99/2198; ô, $^{\circ}$ same data, E, N. Hall, WAM 99/2199.

Diagnosis. Differs from other species of Grayenulla by the abdominal pattern, embolus shape, the form of the seminal reservoir and the massive accessory glands.

\section{Description}

Male holotype. Cephalothorax brown. Eye field with numerous white and orange hairs-numerous and long in its median part and with brown bristles-more numerous anteriorly. Thorax with white hairs. Abdomen with central dark brownish stripe on beige background and dark lateral areas made of narrow lines. Abdomen hirsute, covered with numerous light or dark hairs on light or dark background, respectively. Spinnerets smudged grey-brown. Clypeus brown with yellowish, orange and brown hairs and bristles-less numerous than in other species. Chelicerae honey-brown with 3 promarginal teeth and single bicuspidate retromarginal tooth. Maxillae, labium and sternum brownish, venter beige. Legs I brown, II and III lighter brown, IV—-smudged honey orange. All legs armed with numerous long spines (femora to metatarsi) - almost in oxyopid-like manner. Palpal organ (Fig. 1A-C). Femur with prolateral process, tibia with 2 distinctive apophyses: retrolateral conical, ventrolateral curved distally. Tegulum conical with retrolateral process. Embolus distally daggerlike. Dorsal femora, patellae and tibiae with contrasting long white hairs. Dimensions: CL 2.18, EFL 0.78, AEW 1.45, PEW 1.50, CW 1.71, AL 1.56.

Female. Eye field brownish, eye surrounds darker, thorax smudged brown. Cephalothorax hair cover dense, whitish, adpressed. Ocular area with brown protruding bristles numerous anteriorly. Abdomen (Fig. 1D) round, with distinctive longitudinal brown pattern with yellowish 

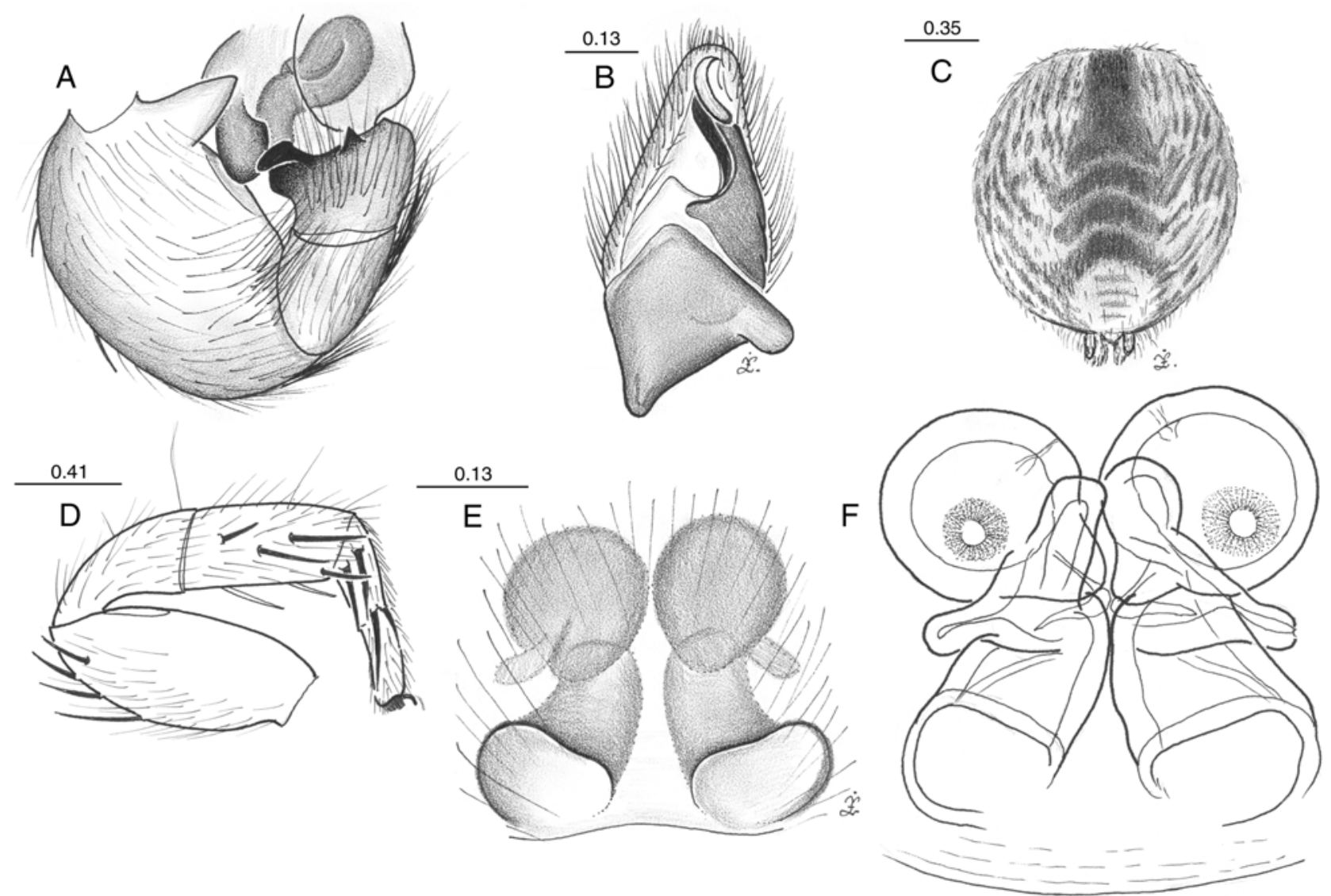

Figure 2. Male and female Grayenulla wilganea n.sp.: A,B, palpal organ; C, male abdominal pattern; D, male leg I; E, epigyne; F, internal genitalia.

margins and rows of smudged orange and grey-brown lateral stripes. Hairs numerous, yellowish and brownish on light and dark areas, respectively. Whole surface also with less numerous brown bristles, same as in male. Anterior and median spinnerets orange, posterior ones brownish. Clypeus orange-brown with numerous white hairs and single long bristles. Chelicerae light-brown with yellow chewing margins, promargin with 2 teeth, retromargin with one tricuspidate tooth. Pedipalps orange with numerous white, yellowish and brown hairs. Maxillae pale orange-yellow, labium brownish, both with pale chewing margins. Sternum smudged orange, with white protruding hairs marginally. Venter light beige with darker central pattern of transverse stripes. First legs rather stout with greyish bands in proximal and distal parts of podomeres. Other legs similar in colour though more delicate. All legs armed with numerous spines. Hair cover moderately dense, whitish and brownish. Bristles brown. Epigyne (Fig. 1E) with distinctive copulatory openings and with 2 posterior pockets. Internal genitalia (Fig. 1F) with unusually massive accessory glands and large oval spermathecae accompanied by their own accessory glands. Dimensions: CL 1.60, EFL 0.60, AEW 1.14, PEW 1.21, CW 1.35, AL 1.60.

Distribution (Fig. 5). Known only from localities in Western Australia.

Etymology. The proposed name refers to the spiny legs.

\section{Grayenulla wilganea n.sp.}

Fig. 2

Type material. HOLOTYPE Australia: New South Wales: 0, Wilganea Station, $5.5 \mathrm{~km} \mathrm{NW}$ of homestead, $90 \mathrm{~km} \mathrm{~N}$ of Burke, 29²1'16"S 146¹6'59"E, 3 Mar 1993, L. Gibson, AMS KS45252. PARATYPES Australia: New South Wales: 30 , + , same data as holotype, AMS KS45279.

Diagnosis. This species is distinguished by its abdominal colour pattern, an embolus that bears a hook-like sclerite, an epigyne without pockets and spermathecae that are relatively small.

\section{Description}

Male holotype. Cephalothorax brown. Eye field with numerous reddish hairs and brown bristles, the latter longer anteriorly. Thorax with numerous white hairs. Abdomen beige, lighter posteriorly, with brown chevrons (Fig. 2C). Spinnerets smudged yellow. Clypeus brown with white hairs, some of them curved down towards chelicerae. Chelicerae brown with lighter chewing margins, promargin with 3 teeth, retromargin with 1 tricuspidate tooth. Maxillae orange, labium smudged brown, both with lighter chewing margins. Venter beige with dark central stripe. All legs yellow except for legs I with darker lateral areas on the femora and smudged orange tibiae. First leg spination as in female (see Fig. 2D). Palpal organ (Fig. 2A,B). Femur very robust with proximal process. Tibia with two apophyses: 

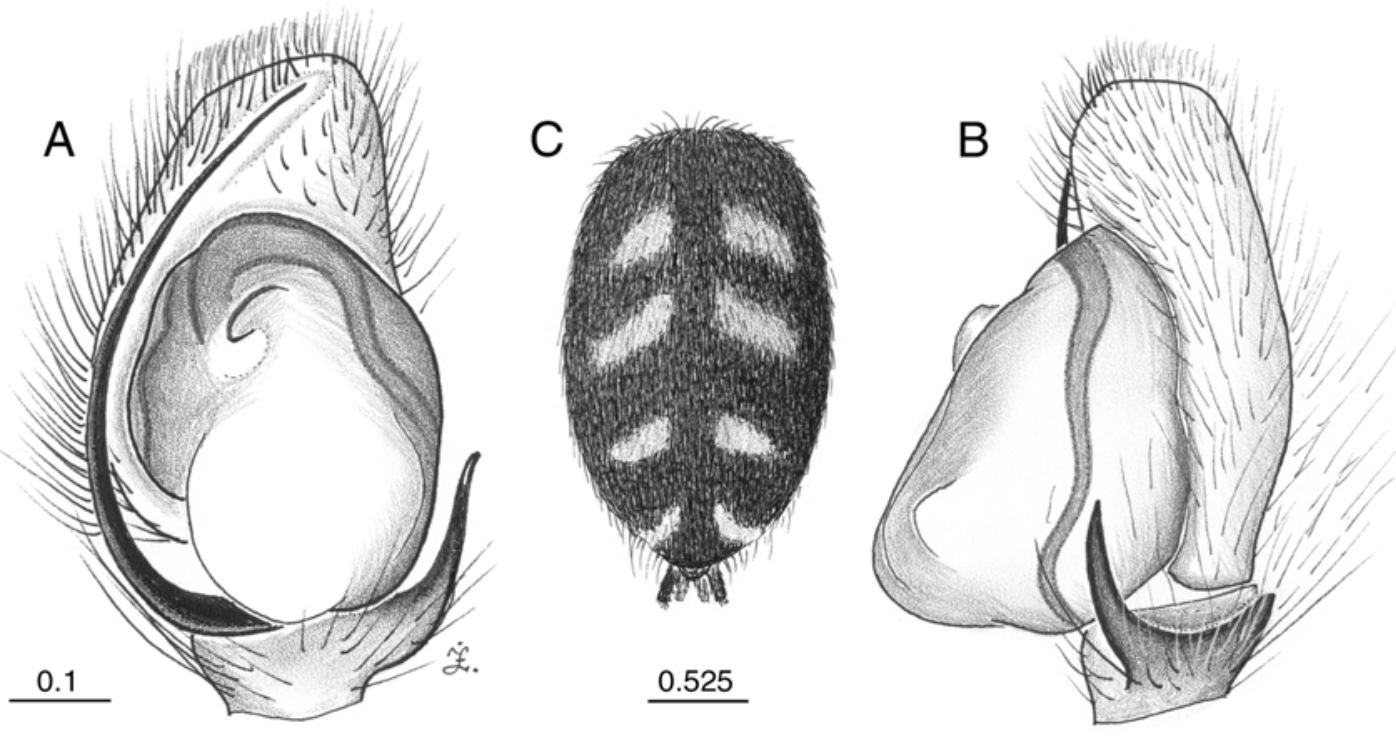

Figure 3. Male Afraflacilla gunbar n.sp.: A,B, palpal organ; C, abdominal pattern.

ventrolateral massive and laterally bent, retrolateral small, conical. Tegulum with 2 posterior lobes, embolus accompanied by large sclerite with hook-like ending. Dimensions: CL 1.57, EFL 0.75, AEW 1.14, PEW 1.07, CW 1.32, AL 1.39.

Female. Thorax brown, eye field darker, eye surrounds black. Whole surface covered with adpressed hairs-white laterally and orange dorsally. Eye field dark with strong dark brown bristles and more delicate, longer bristles around eyes. Abdomen beige with central brownish herring-bone pattern and "panther-like" irregular spots, hair cover of moderate density, light and brownish, with a few brown bristles anteriorly. Spinnerets greyish-yellow. Clypeus darkorange centrally, smudged brown laterally, with numerous white hairs and fewer white and brownish bristles. Chelicerae dark-orange, each with an anterior darker vertical stripe and with yellow chewing margins. Prolateral cheliceral margin with 3 teeth, retrolateral margin with single tricuspidate tooth. Pedipalps orange with yellow and white hairs and brown bristles. Maxillae and labium darkorange with lighter chewing margins. Sternum smudged orange-brown, edged with protruding white hairs. Venter beige, with "panther-like" spots laterally. Legs I moderately robust, yellow-orange, distal femora and joint areas of patella, tibia and metatarsus grey banded. Legs III-IV similar in colour, legs IV with additional prolateral dark femoral stripe. Legs II missing. All legs with numerous orange-brown spines. Hair cover moderate, white, orange and brownish. Epigyne (Fig. 2E-F). Without posterior pockets, copulatory openings well visible, insemination ducts broad with accessory glands. Spermathecae oval but relatively smaller than in other species. Dimensions: CL 2.07, EFL 0.75, AEW 0.92, PEW 0.89, CW 1.24, AL 2.67.

Distribution (Fig. 5). Known only from the type-locality in New South Wales.

Etymology. The proposed name is based on the type locality.

\section{Genus Afraflacilla Berland \& Millot, 1941}

Afraflacilla Berland \& Millot, 1941: 328.

Afraflacilla.-Żabka, 1993: 280.

Type species. Afraflacilla bamakoi Berland \& Millot, 1941: 329 , by original designation.

\section{Afraflacilla gunbar n.sp.}

Fig. 3

Type material. HoLOTYPE Australia: New South Wales: ๙。, $2 \mathrm{~km}$ E of Gunbar, $34^{\circ} 3^{\prime} \mathrm{S} 145^{\circ} 24^{\prime} \mathrm{E}$, ex nest of Badumna candida, 25 Apr 1987, M.R. Gray, AMS KS17618.

Diagnosis. This species has distinctive abdominal patterning and palpal organ form.

\section{Description}

Male. Thorax light brown. Eye field darker with black eye surrounds, central longitudinal stripe of white hairs and brown bristles-most numerous anteriorly. Sides orange, with numerous white hairs and with stridulatory tubercles (10 and 13 at left and right sides, respectively). Lower margins darkgrey. Abdomen (Fig. 3C) greyish-brown, darker centrally with light pattern of paired spots. Dark-grey hairs and less numerous bristles present along central and lateral sides. Spinnerets greybrown. Clypeus orange with numerous white hairs and with 3 central brown bristles. Eyes surrounded with orange scale-like hairs. Chelicerae light-brown with 2 prolateral teeth and 1 retrolateral tooth. Maxillae and labium elongate, orange with lighter chewing margins. Sternum smudged orange, darker marginally. Venter beige. First legs massive, dark-orange, femora with 5-6 stridulatory tubercles, tibiae with a single anterolateral spine and metatarsi with 2 pairs of short spines. Palpal organ (Fig. 3A,B). typical for the genus. Tegulum with anterior process, embolus curving around the tegulum. Tibial apophysis long and thin with dorsolateral process. Dimensions: CL 1.82, EFL 0.71, AEW 0.92, PEW 0.87, CW 1.21, AL 2.42.

Distribution (Fig. 5). Known only from localities in New South Wales.

Etymology. The proposed name is based on the type locality. 


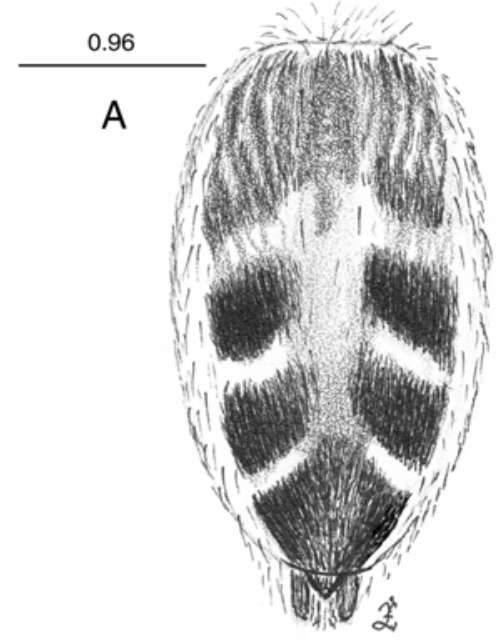

Figure 4. Female Afraflacilla milledgei n.sp.: A, abdominal pattern; $\mathrm{B}$, epigyne; $\mathrm{C}$, internal genitalia.

\section{Afraflacilla milledgei n.sp.}

Fig. 4

Type material. HOLOTYPE Australia: Western Australia: + , Kimberley Region, Great Northern Highway, $52 \mathrm{~km} N$ of Turkey Creek, $16^{\circ} 38^{\prime} 05^{\prime \prime S} 128^{\circ} 11^{\prime} 38^{\prime \prime E}$, beating savannah woodland, 9 Jun 1999, M. Gray, G. Milledge, H. Smith, AMS KS59857.

Diagnosis. This species can be recognised by its epigyne and internal genitalia.

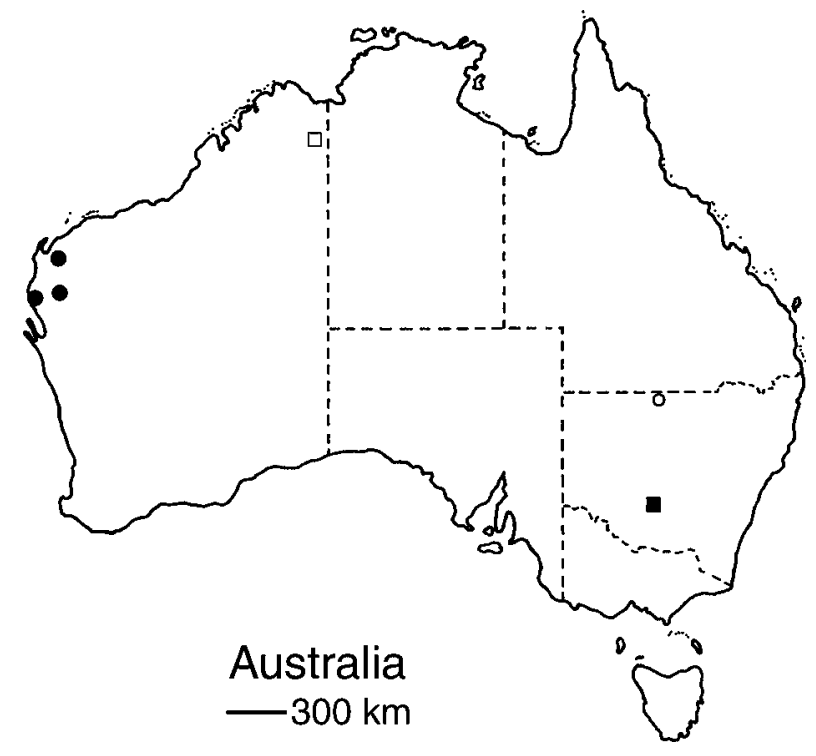

Figure 5. Distributions of Grayenulla spinimana $\bullet$, Grayenulla wilganea $\bigcirc$, Afraflacilla gunbar $\mathbf{-}$, and Afraflacilla milledgei $\square$.
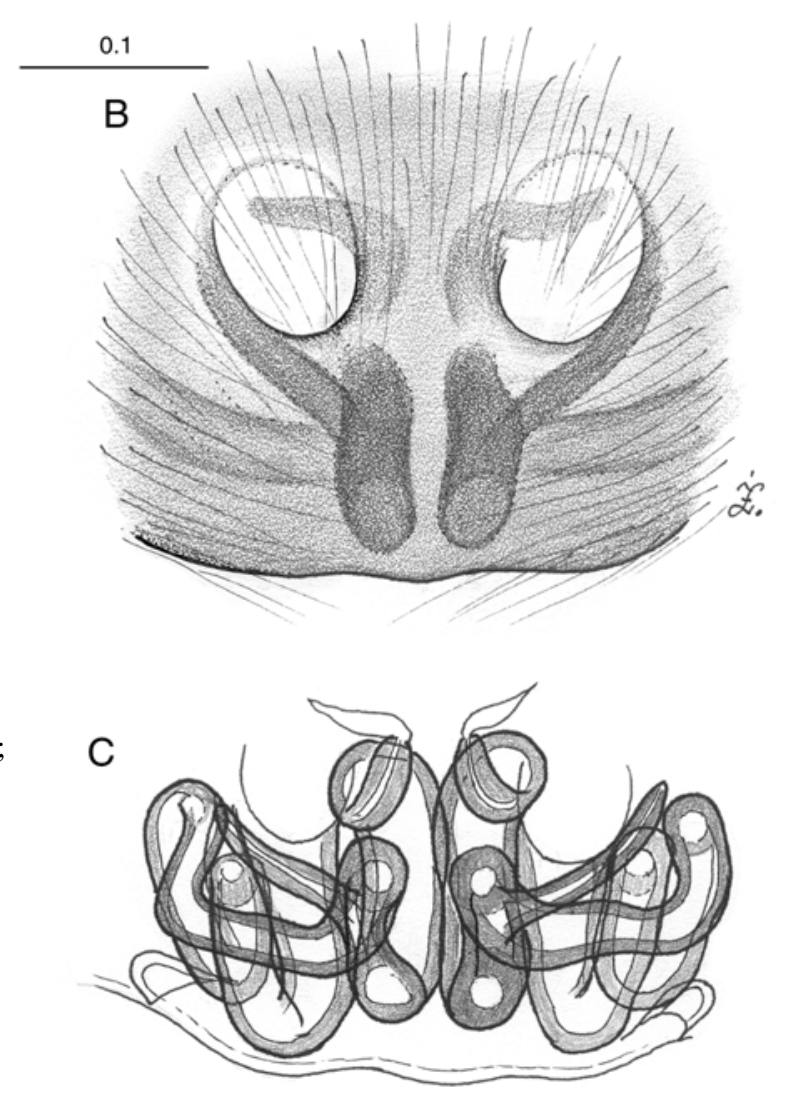

\section{Description}

Female. Thorax brown with radial pattern of darker lines. Eye field brown-black. Fovea region and lateral thorax orange, the latter with a narrow dark grey marginal band. 11 and 9 stridulatory tubercles on left and right side of cephalothorax, respectively. Cephalothorax covered with numerous white hairs, eye field with additional brown bristles-most numerous anteriorly. Abdomen (Fig. 4A) with yellowish and dark pattern, the latter made of pigment and dense hairs. Clypeus orange, densely covered with white scale-like and longer yellowish hairs. Chelicerae dark orange with 2 prolateral teeth and 1 retrolateral tooth. Pedipalps yellow, covered with long yellowish hairs. Legs yellow with sparse white hair cover and long brown bristles. Femora I with 5-6 stridulatory tubercles. Epigyne (Fig. 4B,C) relatively short, with 2 anterior depressions and translucent internal structures. Insemination ducts long and coiled, distally more sclerotised, spermathecae in the form of parallel central channels, fertilisation ducts distinctive, epigynal pockets located posteriorly — close to the epigastric furrow. Dimensions: CL 1.92, EFL 0.78, AEW 1.03, PEW 1.14, CW 1.24, AL 2.57.

Distribution (Fig. 5). Known only from the type-locality in Western Australia.

Etymology. For Graham Milledge, Collection Manager, Arachnology Department, Australian Museum, Sydneyone of the collectors of the material studied. 
ACKNOWLEDGMENTS. The material studied here was collected during biodiversity surveys conducted by the Australian Museum and was kindly made available by Mr G. Milledge. Dr M. Harvey and Ms J. Waldock (Western Australian Museum, Perth) sent specimens from Western Australia. M. Żabka's visit in Australia was made possible thanks to a Visiting Fellowship offered by the Australian Museum and through co-operation of the staff of the Arachnology Department. Prof. J. Prószyński (Warszawa, Poland) provided critical remarks on Afraflacilla.

\section{References}

Berland, L., \& J. Millot, 1941. Les araignées de l'Afrique Occidentale Française. I-Les salticides. Mémoires du Muséum National d'Histoire Naturelle 12: 297-424.

Berry, J.W., J.A. Beatty \& J. Prószyński, 1998. Salticidae of the pacific Islands III. Distribution of Seven Genera With Description of Nineteen New Species and Two New Genera. Journal of Arachnology 26: 149-189.

Bohdanowicz, A., 1988. Salticidae from the Nepal Himalayas. The genus Synagelides Bösenberg \& Strand, 1906. Curier des Forschungs-Instituts Senckenberg 93: 65-86.
Galiano, M.E., 1987. Descripcion de Hirsukattus nuevo genero (Araneae, Salticidae). Revista de la Sociedad de entomólogica argentina 44(2): 137-148.

Prószyński, J., 1992. Salticidae (Araneae) of the Old World and Pacific Islands in several US collections. Annales Zoologici 44: 87-163.

Żabka, M., 1991. Salticidae (Arachnida: Araneae) of Oriental, Australian and Pacific Regions, VI. Mopsolodes, Abracadabrella and Pseudosynagelides-new genera from Australia. Memoirs of the Queensland Museum 30: 621-644.

Żabka, M., 1992. Salticidae (Arachnida: Araneae) of Oriental, Australian and Pacific Regions, VII. Grayenulla and Paraplatoides-new genera from Australia. Records of the Australian Museum 44: 165-183.

Żabka, M., 1993. Salticidae (Araneae) of Oriental, Australian and Pacific Regions, IX. Genera Afraflacilla Berland \& Millot, 1941 and Evarcha Simon, 1902. Invertebrate Taxonomy 7: 279-295.

Manuscript received 14 June 2000, revised 14 July 2001 and accepted 14 August 2001.

Associate Editor: D.J. Bickel. 